\title{
The Next Frontier: Restoring the World's Oceans
}

We call it "Earth," but wouldn't "Oceana" be a more appropriate name for the third planet from the Sun? After all, it is the only planet in our solar system that has liquid water, and it has it in abundance, with nearly 71 percent of its surface covered by water, 69 percent of which is saltwater.

It was the Greeks (Gaea, Earth Mother), Romans (Tellus, goddess of the fertile soil), and eventually the Germans (Erda meaning the soil, ground; from the Germanic earth goddess, Erd) who saddled the English language with the notion of humans living on a planet whose main physical component was solid and firm, rather than wet and liquid. As a result, even Leopold's Land Ethic fails to give the watery part of the planet its due. In fact, of all the mid-20th century writer-naturalists only Rachel Carson in Under the Sea Wind (1941), The Sea Around Us (1951), and The Edge of the Sea (1955) seems to have grasped the primordial and present-day importance of the oceans and their ecosystems.

As geographer Philip E. Steinberg points out in The Social Construction of the Ocean, most people have basically forgotten about oceans or conceptualized them as space where activities, such as battles, experiments, resource extraction, and transportation, take place in an unearthly realm. Thus, the ability of great novels, such as Moby Dick, and The Old Man and the Sea, to take us into an "other" world to help explain the essence of the human condition and our relation to Nature. Indeed, outside of the 200-nautical mile limit set by the Third United Nations Convention on Law of the Sea, oceans exist as free space-space outside the regulation of any one nation, and one generally ignored by the public.

Globalization and postmodern capitalism are changing that approach, however. Oceans can no longer be regarded as some area outside the everyday existence of humanity. Moreover, they must be considered as part of the whole when we think about our environment - and our conservation and restoration of the same.

The need to turn our attention to the conservation and restoration of oceans was made public business in 2003 with the release of the Pew Ocean Commission's America's Living Oceans: Charting a Course for Sea Change and the International Council for the Exploration of the Sea's Environmental Status of the European Seas. These two major reports on the conditions and problems of marine environments were followed in 2004 by the United States Commission on Ocean Policy, which delivered the final version of its report, An Ocean Blueprint for the 21st Century, to President Bush and the Congress on September 20. Each of these reports outlines the silent ruin of our planet's ocean ecosystems. They review the basic problems-collapsing fisheries, excessive coastal development, harmful pollution, excessive nutrient enrichment, invasive species, and declining marine biodiversity — and their solutions, which include policy changes and a greater emphasis on preservation, maintenance, and ecological restoration of marine systems.

I believe this emphasis on oceans represents a great opportunity-one that will usher in a new frontier for the ecological restoration community. But returning the deep oceans and productive coastal waters to sustainable condition will undoubtedly require a holistic approach. Restorationists will need to work with and support programs that develop responsible techniques for both coastal and deep-sea fishing, promote ecologically sound aquacultural practices, and create and maintain protected marine reserves. Embedded in all of these activities will be restorationoriented research projects, like experiments to determine whether adding iron to high-nitrate, low-chlorophyll regions of the ocean will increase phytoplankton. We will also need to support stronger regulation of coastal zone development, and not become involved in mitigation plans that serve to endanger coastal resources. Restorationists in the United States can also review and comment on proposed legislation that would strengthen federal ocean policy and create permanent trust funds for improving both research and habitat restoration.

We must extend Leopold's Land Ethic to the entire planet, including its oceans, if we are to be the stewards of this orb. Not to do so, would be to ignore the Other-the deep oceans and coastal waters we all must cross.

Dave Egan 